\title{
Towards Unimolecular Luminescent Solar Concentrators: Bodipy- Based Dendritic Energy-Transfer Cascade with Panchromatic Absorption and Monochromatized Emission**
}

\author{
O. Altan Bozdemir, Sundus Erbas-Cakmak, O. Oner Ekiz, Aykutlu Dana, and \\ Engin U. Akkaya*
}

Today, efficient and effective utilization of solar energy is a high-priority target and is expected to be even more so in the near future. ${ }^{[1]}$ For the large-scale exploitation of the stellar energy source, cost is always the major prohibitive item. The use of polycrystalline silicon, ${ }^{[2]}$ amorphous thin films of silicon, ${ }^{[3]}$ or alternative semiconducting materials such as $\mathrm{Cu}(\mathrm{In}, \mathrm{Ga}) \mathrm{Se}_{2}$ (CIGS) ${ }^{[4]}$ together with dye-sensitized solar cells ${ }^{[5]}$ already have or are expected to have big impacts on the production costs, but more effort in all aspects of the solar energy transduction is needed. One approach is to break down this massive problem into relatively easily addressable components, such as absorption of solar photons and conversion of absorbed solar energy into electricity. Installation and transmission of the produced electrical energy are two other components, which are essentially engineering problems. For the efficient absorption of the solar radiation component, it has been known for some time that even without major changes in solar cell design, it should be possible to obtain substantial enhancements by making use of solar concentrators. ${ }^{[6]}$ Optical solar concentrators have been around for the last four or five decades, however, overheating is always a troublesome issue, with an additional need for solar tracking with most optical concentrators. ${ }^{[7]}$ Luminescent solar concentrators on the other hand seem to be more promising. ${ }^{[8]}$ Conversion of the incident solar radiation into monochromatized light is expected to lead to a large enhancement in the efficiency of solar cells. Key features of the luminescent solar concentrators are the dispersed dye or dyes in a transparent waveguide. Through total internal reflection, reemitted light is trapped within a plastic or glass matrix, and photovoltaic units are fixed to the sides through which the light is channelled out. The advantages are striking: no tracking or cooling is needed and much smaller areas have to be covered by expensive solar-cell components. However,

[*] Dr. O. Altan Bozdemir, S. Erbas-Cakmak, O. O. Ekiz, Dr. A. Dana, Prof. Dr. E. U. Akkaya UNAM-Institute of Materials Science and Nanotechnology Bilkent University, Ankara 06800 (Turkey) E-mail: eua@fen.bilkent.edu.tr

Prof. Dr. E. U. Akkaya

Department of Chemistry, Bilkent University 06800 Ankara (Turkey)

[**] We are grateful for funding by BOREN, Turkish academy of Sciences (TUBA), and State Planning Organization (DPT).

9 Supporting information for this article is available on the WWW under http://dx.doi.org/10.1002/anie.201104846. such concentrators are not free from problems; self absorption of the emitted light is a major problem. ${ }^{[9]}$ Recently a different luminescent concentrator design that made use of a mixture of dyes in amorphous thin films placed in a tandem design with one terminal absorber was reported. ${ }^{[10]}$ The other two dyes absorb light at different wavelengths and are expected to transfer the excitation energy to the terminal absorber. The intermolecular Förster energy transfer (FRET) was invoked as the operational mechanism of the energy transfer. With the assumption of efficient intermolecular energy transfer in the solid (gel) phase, the only emission will be at the longer wavelength region with large pseudo-Stokes shifts, thus minimizing self-absorption.

The intermolecular energy-transfer efficiency is an important limiting factor that requires high concentrations of the dyes for optimal results, but higher concentrations will lead to larger losses caused by self-absorption. ${ }^{[9]}$ Herein, we propose that this apparent dilemma can be addressed at least in principle, by replacing a cocktail of dyes with a dendritic lightharvesting energy gradient with a core molecule as the terminal absorber and emitter. In the dendritic system, energy-transfer efficiency will remain high, regardless of its concentration within the matrix.

Unimolecular energy gradients have been reported previously ${ }^{[11]}$ with a number of peripheral antenna molecules and a core chromophore absorbing at a longer wavelength. Typically, they are characterized in solution. In this work however, we explicitly targeted an energy cascade system SC composed of bodipy dyes (see below) with varying degrees of substitution with styryl groups. This approach will ensure strong absorption in most parts of the visible spectrum, however, through efficient energy-transfer processes, emission is expected to originate only from the terminal absorber. An optimal solar cell placed on the sides of the matrix is expected to produce efficient and cost-effective conversion. In addition, we wanted to demonstrate the efficiency of every single step of cascading energy transfers; to that end we synthesized energy-transfer modules of ET-1, ET-2, and ET-3.

Bodipy dyes are highly versatile chromophores ${ }^{[12]}$ and can be conveniently derivatized ${ }^{[13]}$ to span the entire visible spectrum and beyond, showing exceptional photochemical and photophysical qualities. These properties of Bodipy dyes, including sharp absorption and emission maxima, were previously exploited in energy-transfer modules. In our design, the goals were to optimize the absorption in a large part of the visible spectrum and also the conversion to emission centered at $672 \mathrm{~nm}$, which is ideally suited for 


\section{Communications}

efficient photovoltaic conversion when coupled to a GaAs or InGaAs solar cell.

The envisioned synthesis makes use of a convergent dendrimer build-up approach (Scheme 1) with strategically placed Huisgen-type click components (terminal alkyne and azide groups). This approach not only allows the synthesis of final target compounds but also various modules of energy transfer can be synthesized in a straightforward sequence of reactions. Synthesis details and the compound structures are given in the electronic Supporting Information.
The absorption, emission, and excitation spectra of the dendritic concentrator and the reference energy-transfer modules were acquired in chloroform. Absorption spectra show bands in accordance with the number and the type of chromophore units. The absorption maximum for peripheral bodipy units is located at $527 \mathrm{~nm}$, the one for intermediate monostyryl-bodipy units at $590 \mathrm{~nm}$, and the one for core distyryl-bodipy at $655 \mathrm{~nm}$, respectively (Figure 1). Eight peripheral antenna bodipy chromophores present a large absorption cross-section $\left(540000 \mathrm{M}^{-1} \mathrm{~cm}^{-1}\right)$ in the middle of

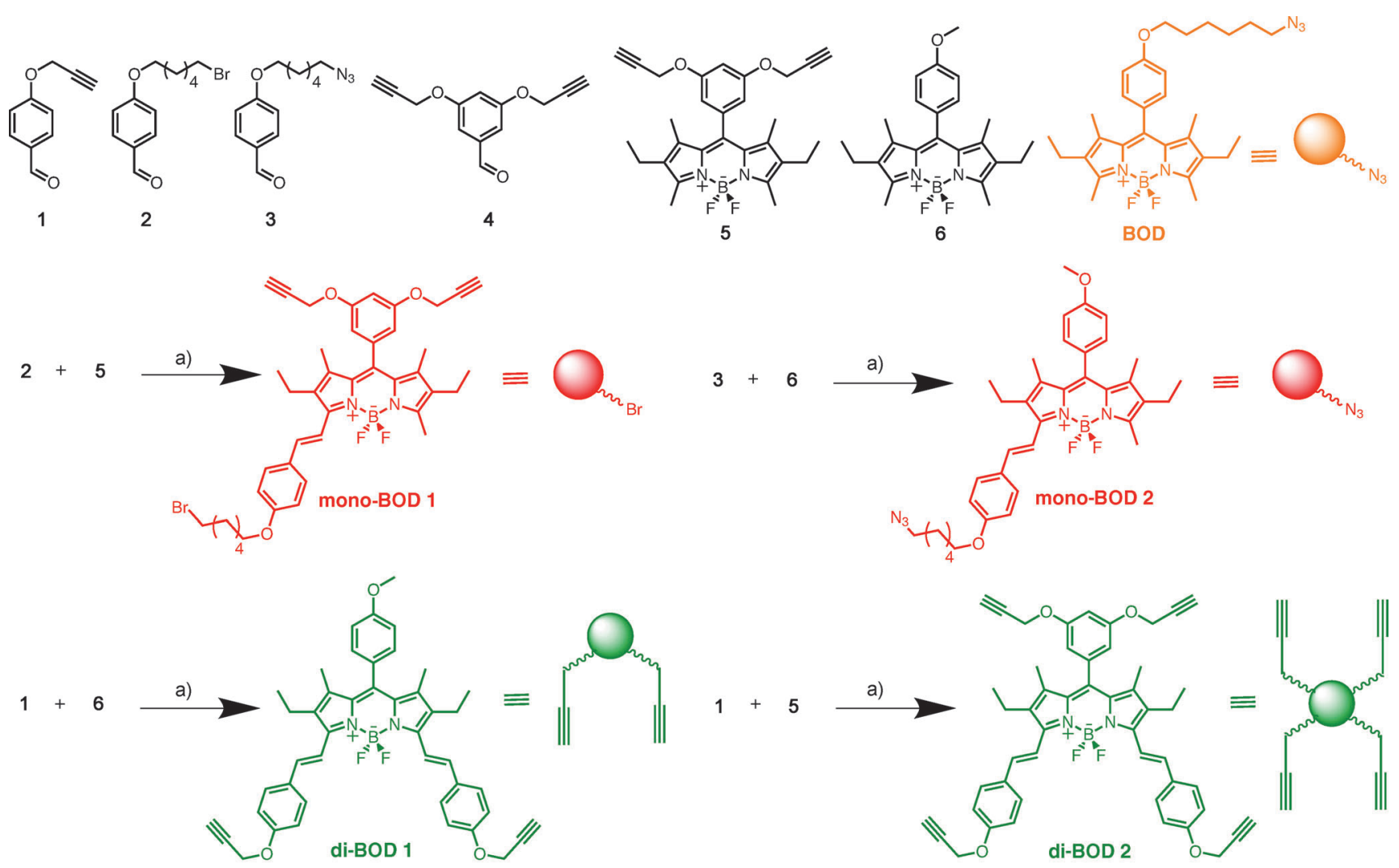

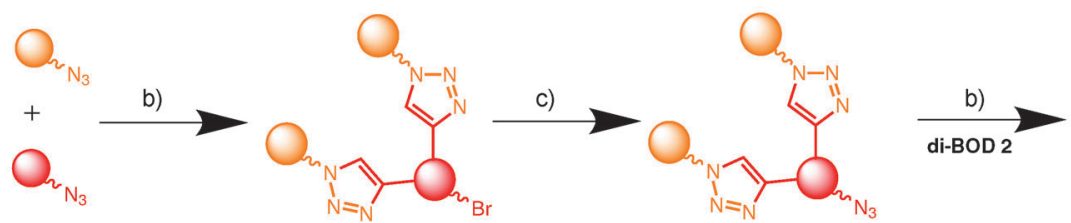

MET-1

(7)
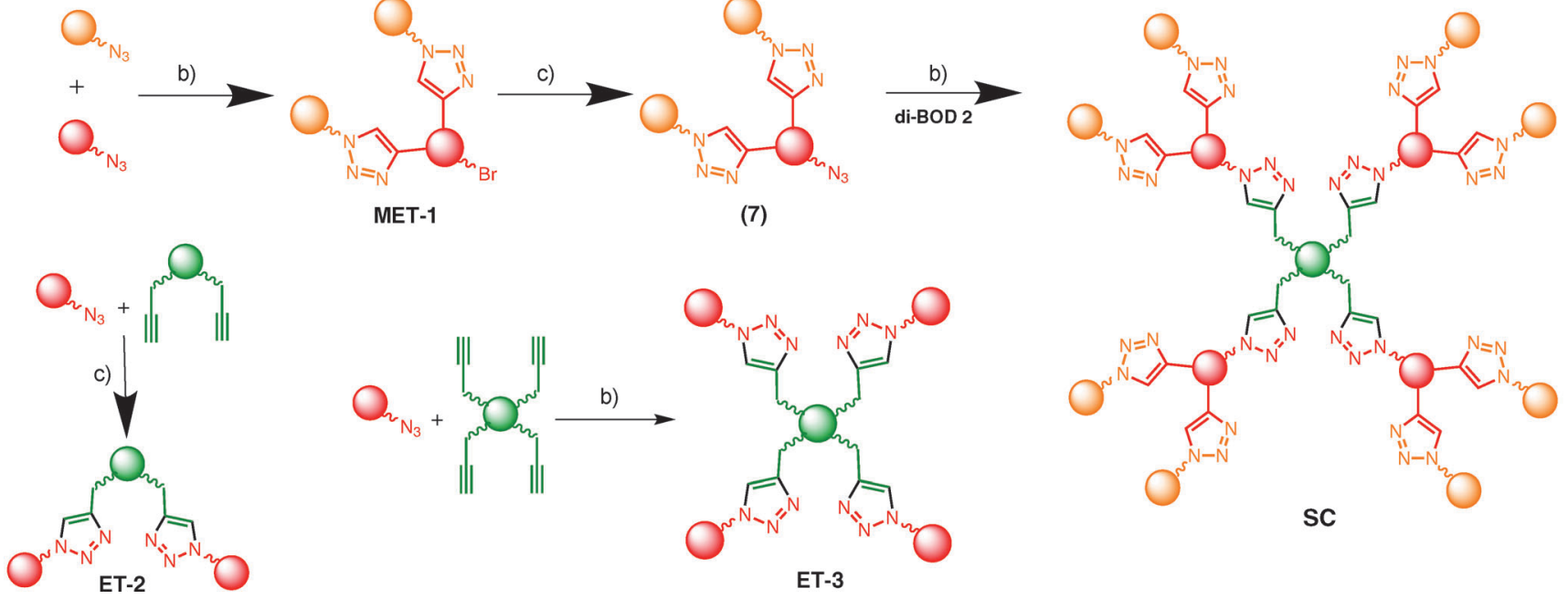

Scheme 1. Synthesis and schematic representations of ET molecules and $\mathrm{SC}$. a) piperidine, $\mathrm{AcOH}$, benzene, reflux; b) $\mathrm{CuSO}_{4} \cdot 5 \mathrm{H}_{2} \mathrm{O}, \mathrm{Et}_{3} \mathrm{~N}, \mathrm{Sodium}$ Ascorbate, THF: $\mathrm{H}_{2} \mathrm{O} ; \mathrm{c}$ ) $\mathrm{NaN}_{3}, \mathrm{~B} 18 \mathrm{C} 6$, acetonitrile, $60^{\circ} \mathrm{C}$. Synthetic procedures for each aldehyde, compounds 5, 6, and all other reaction details and explicit structures can be found in the Supporting Information. 


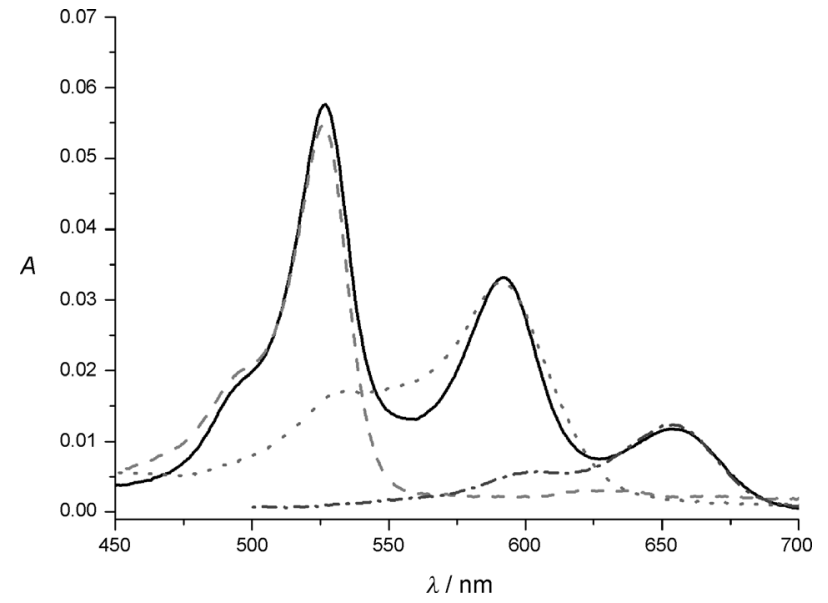

Figure 1. Absorption spectra (in $\mathrm{CHCl}_{3}$ ) of the target solar concentrator SC and separate chromophoric units Bod (dashed), mono-BOD-2 (dot), di-BOD-2(dashed-dot) functionalized with "clickable" groups. Concentrations of the dyes were adjusted so that the dyes have equal absorbance at the maxima.

the visible range, whereas four monostyryl-bodipy dyes absorb in the yellow-orange region of the visible spectrum. Emission spectra collected by exciting the chromophores at different wavelengths show energy funneling in accordance with our design goals. Excitation spectra obtained at $675 \mathrm{~nm}$ show direct evidence of energy transfer with sharp shorterwavelength maxima that correspond to energy flow from the peripheral antenna units to the red-emitting core (Figure 2). Energy transfer modules (ET1-3) have been helpful in establishing the efficiency of energy transfer along the cascade. Thus, we determined maximal energy-transfer efficiencies of $98 \%$ in the module ET-1 based on the decrease in excited-state lifetimes, $91 \%$ for ET-2, and $93 \%$ in ET-3, based on changes in the quantum yields of the energy-donor moieties (Figure 3).

SC also shows highly efficient energy-transfer cascades between the spectrally divergent chromophores. The outer-

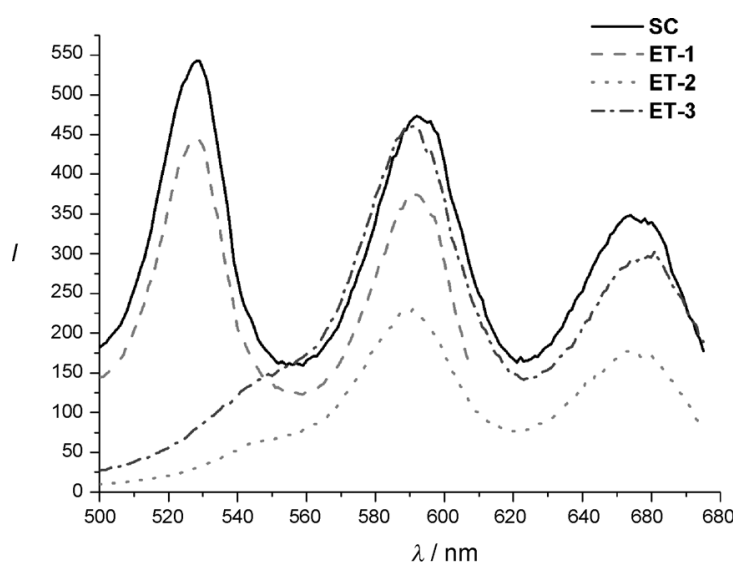

Figure 2. Excitation spectra of SC (solid) and the energy-transfer modules ET-1 (dashed), ET-2 (dot), ET-3 (dashed-dot). Emission data were collected for excitation at $605 \mathrm{~nm}$ in the case of ET-1 and $675 \mathrm{~nm}$ for the other ET modules and SC.

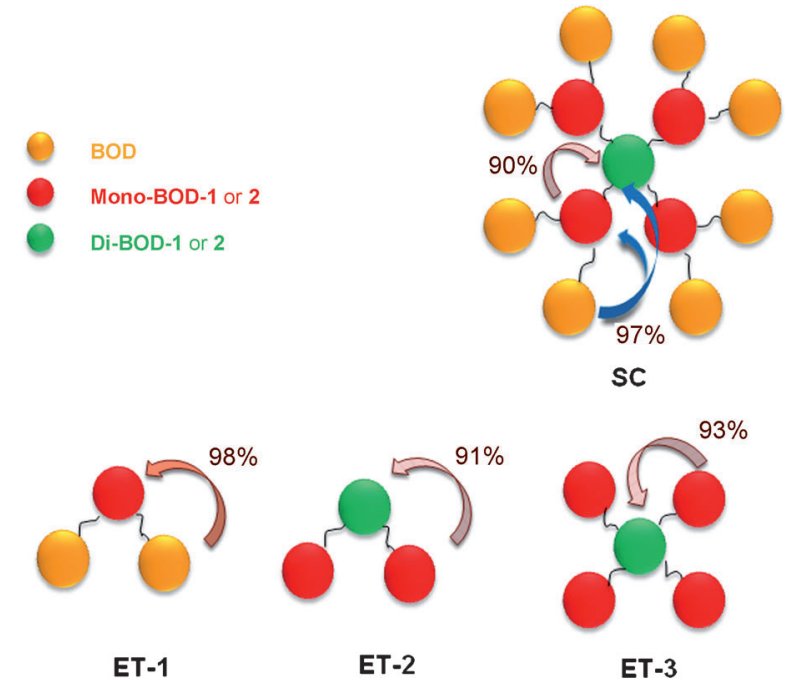

Figure 3. Schematic representations of ET modules and the solar concentrator SC with relevant energy-transfer-efficiency values. Calculations are based on either quantum yield (ET-2, ET-3, SC) or lifetime (ET-1) changes.

most shorter wavelength absorbing chromophores transfer energy to the mono-styryl and distyryl core unit with a total efficiency of $97 \%$. Intermediate monostyryls are also efficient in transferring energy to the core unit $(90 \%)$. The emission spectrum of the SC shows residual peaks corresponding to direct emission from the outer chromophores. However, this emission leak is insignificant compared with the emission peaks of the FRET-decoupled "free" bodipy dyes of comparable structure in the dye mixture (Figure 4). Table 1 lists
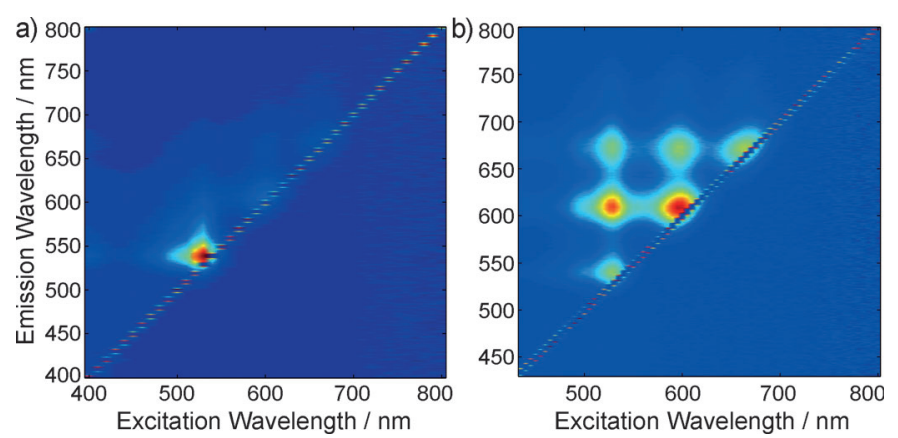

Figure 4. Emission versus excitation spectra: a) dye mixture (BOD, monoBOD-2, and di-BOD-2) and b) SC $(2.5 \mu \mathrm{M})$ in epoxy resin. Dye concentrations were adjusted to have absorbance values equal to that of $\mathbf{S C}$ at the peak values.

relevant photophysical parameters for energy transfer. Energy-donor moieties show decreased quantum yields with concomitant reduction in the emission lifetime as expected.

Another important parameter to be considered for solar concentrators is the self-absorption within the dye assembly, which is often quantified by a factor $\mathrm{S}$. This factor is the ratio of the absorbance of the energy donor at its maximum value to the absorbance at the emission maximum of the acceptor 
Table 1: Molar absorption coefficients, emission lifetimes, absorption, and emission maxima, energy-transfer efficiencies and rate constants of the dendrimer SC and relevant compounds synthesized herein.

\begin{tabular}{|c|c|c|c|c|c|c|c|c|c|}
\hline Dye & $\begin{array}{l}\lambda_{\text {abs }} \\
{[\mathrm{nm}]}\end{array}$ & $\begin{array}{l}\varepsilon \\
{\left[\mathrm{M}^{-1} \mathrm{~cm}^{-1}\right]}\end{array}$ & $\begin{array}{l}\lambda_{\mathrm{F}} \\
{[\mathrm{nm}]}\end{array}$ & $\begin{array}{l}\phi_{\mathrm{F}}^{[\mathrm{a}]} \\
{\left[\lambda_{\mathrm{exc}}(\mathrm{nm})\right]}\end{array}$ & $\begin{array}{l}\tau_{1}{ }^{[\mathrm{b}]} \\
{[\mathrm{ns}]}\end{array}$ & $\begin{array}{l}\tau_{2}^{[\mathrm{b}, \mathrm{c}]} \\
{[\mathrm{ns}](\%)}\end{array}$ & $\begin{array}{l}\tau_{3}{ }^{[\mathrm{b}]} \\
{[\mathrm{ns}]}\end{array}$ & $\begin{array}{l}K_{\mathrm{ET}}^{[\mathrm{d}]} \\
{\left[\times 10^{-9} \mathrm{~s}^{-1}\right]}\end{array}$ & $\varepsilon_{\mathrm{ET}}^{[\mathrm{d}]}$ \\
\hline BOD & 526 & 76000 & 539 & $0.80(488)$ & 4.30 & - & - & - & - \\
\hline mono-BOD-1 & 590 & 59000 & 605 & $0.85(550)$ & - & 5.57 & - & - & - \\
\hline mono-BOD-2 & 590 & 63000 & 605 & $0.89(550)$ & - & 4.57 & - & - & - \\
\hline di-BOD-1 & 651 & 71000 & 670 & $0.67(610)$ & - & - & - & - & - \\
\hline di-BOD-2 & 653 & 72000 & 672 & $0.68(610)$ & - & - & 4.97 & - & - \\
\hline \multirow[t]{2}{*}{ ET-1 } & 527 & 120000 & 539 & $0.14(488)$ & 0.07 & 5.27 & - & 11.42 & 0.98 \\
\hline & 590 & 61000 & 605 & $0.39(550)$ & & & & & \\
\hline \multirow[t]{2}{*}{ ET-2 } & 590 & 132000 & 605 & $0.08(550)$ & - & $2.75(36)$ & 5.67 & 2.21 & 0.91 \\
\hline & 654 & 64000 & 672 & $0.42(610)$ & & $5.45(64)$ & & & \\
\hline \multirow[t]{2}{*}{ ET-3 } & 590 & 270000 & 605 & $0.06(550)$ & - & 1.85 (13) & 4.54 & 2.90 & 0.93 \\
\hline & 656 & 88000 & 672 & $0.31(610)$ & & $4.28(87)$ & & & \\
\hline \multirow[t]{3}{*}{ SC } & 527 & 540000 & 539 & $0.02(488)$ & 0.11 & 0.87 (12) & 4.46 & $7.52^{[\mathrm{e}]}$ & $0.97^{[\mathrm{e}]}$ \\
\hline & 590 & 299000 & 605 & $0.09(550)$ & & $4.16(88)$ & & $1.97^{[f]}$ & $0.90^{[f]}$ \\
\hline & 655 & 82000 & 672 & $0.32(610)$ & & & & & \\
\hline
\end{tabular}

[a] Quantum yields were calculated using rhodamine $\mathrm{G} 6$ (excitation at $488 \mathrm{~nm}$ in $\mathrm{H}_{2} \mathrm{O}$ ), sulforhodamine 101 (excitation at $550 \mathrm{~nm}$ in EtOH) and cresyl violet (excitation at $610 \mathrm{~nm}$ in $\mathrm{MeOH}$ ) as standard chromophores. Integration values for each $\Phi_{\mathrm{F}}$ data point was obtained by selecting the area under the corresponding emission maximum. [b] The dye laser excitations were carried out at 495,609 , and $667 \mathrm{~nm}$ for $\tau_{1}, \tau_{2}$, and $\tau_{3}$ respectively. [c] The two different values are caused by two exponential decay models, contribution percentages to decay are shown in parentheses. Decay paths with contributions less than $1 \%$ were neglected. [d] Steady-state approach based on change in quantum yields was used for ET-2, ET-3, SC (excitation at $590 \mathrm{~nm}$ ). For all other compounds, a time-resolved approach based on decrease in lifetime was used. [e] The calculation was carried out using the change in $\tau_{1}$. [f] The calculation was carried out using the change in $\phi_{\mathrm{F}}$ at $605 \mathrm{~nm}$.

dye (terminal chromophore). The outer, unmodified bodipy units thus give an S factor of 10000 in SC; which is a truly remarkable value, showing the potential of bodipy-based dendritic cascades in solar concentrator design.

To further illustrate the superiority of the unimolecular energy-cascade design, we acquired comparative excitation versus emission spectra for the $\mathbf{S C}$ and a collection of the individual dyes (BOD, mono-BOD-2, and di-BOD-2) at absorbance values equal to that of $\mathrm{SC}$ at their respective maxima in epoxy resin waveguide slabs (Figure 4). The data clearly shows energy transfer from the periphery to the core in SC with almost total annihilation of the peripheral emission. With the simple mixture of dyes in a polymer matrix, most of the emission originates from the shortestwavelength dye without much of an energy transfer (Figure 4 a). Emission and excitation spectra of SC and ET molecules in solution (Figure S2-S14) and in epoxy resin (Figure S15-S17) can be found in the Supporting Information.

The emission from the dye mixture and the molecular concentrator SC embedded in an epoxy slab was investigated as a function of the distance between excitation and emission positions. The refractive index of the slab was $n=1.5$ and the emitted light was partially captured in the slab by total internal reflection. In each absorption/emission event, about $75 \%$ of the light is retained in the slab, and approximately $25 \%$ escapes. The slab was excited by a $0.5 \mathrm{~mm}$ diameter laser beam at $532 \mathrm{~nm}$ wavelength and the emitted light was collected at the edge of the slab by an optical fiber connected to a spectrometer (Figure 5a). As the position of the excitation spot is changed away from the edge, the collected light shows changes both in intensity and in spectral distribution. It is experimentally observed that for the dye mixture, caused by self-absorption and escape losses, spectral conversion is limited and the output spectrum is concentrated
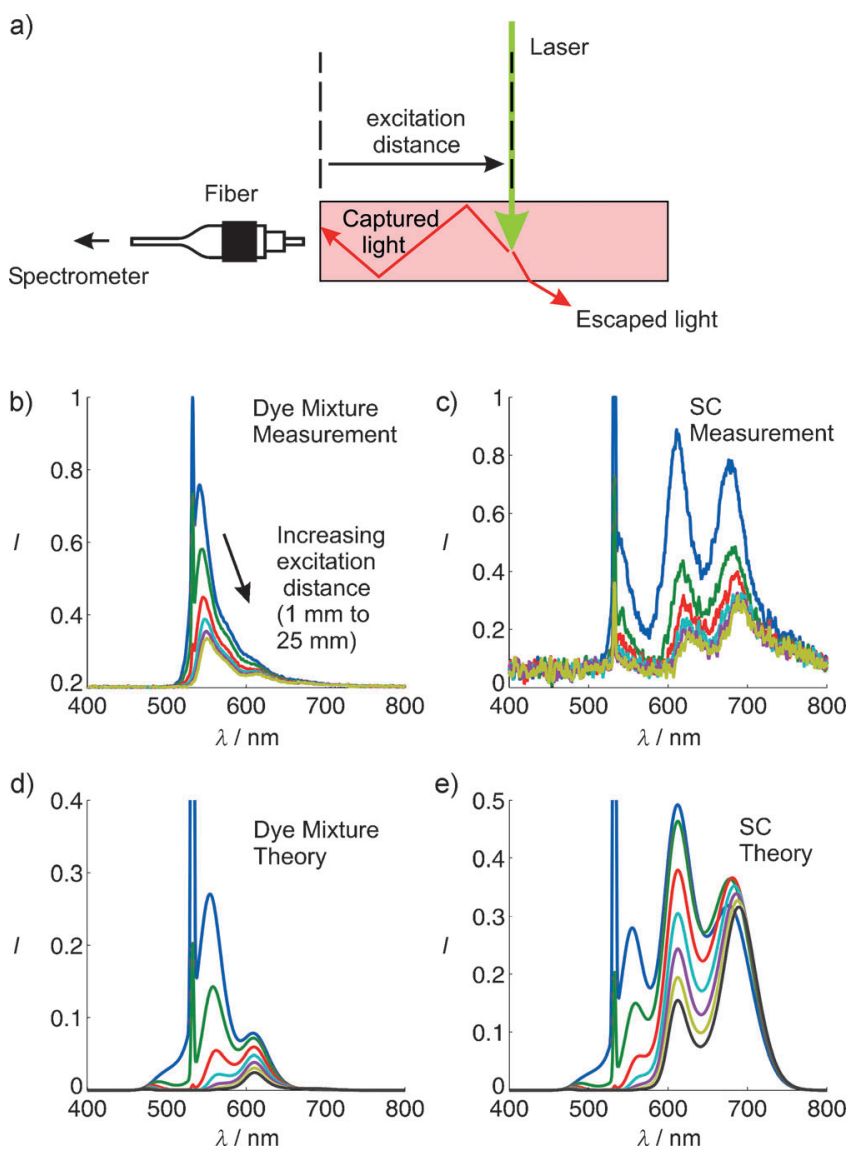

Figure 5. a) Pictorial representation of the experimental setup for the acquisition of excitation-distance-dependant spectra. b,c) Monte Carlo simulation and d,e) experimental results showing the distance dependence of emission spectra of the dye mixture (BOD, mono-BOD-2, and di-BOD-2) and equally absorbing SC both in clear epoxy resin. 
mainly to the emission of the peripheral bodipy dyes around $550 \mathrm{~nm}$ (Figure 5b). For the SC however, it is clear that spectral conversion is more efficient and low-energy light (around $700 \mathrm{~nm}$ ) is more effectively retained in the slab and delivered to the sides (Figure 5b). Monte Carlo (MC) analysis was used to estimate the spectra of photon fields inside dyedoped slabs (see the Supporting Information for details). MC analysis qualitatively predicts the distance-dependent spectral distribution for the dye mixture without energy transfer (Figure 5d) and for SC with intramolecular energy transfer (Figure $5 \mathrm{e}$ ). It must be noted however, that in the MC simulations, absolute energy-transfer efficiencies for excitation energy transfer (EET) processes are found to be about $30 \%$ by steady-state or time-resolved measurements as opposed to $95 \%$ calculated. The energy-transfer efficiencies of $30-40 \%$ estimated by fitting of MC analysis results to measured spectra (Figure $4 \mathrm{a}, \mathrm{b}, 5 \mathrm{~b}$, and c) highlight the fact that calculations based on just the changes in donor-emission lifetime and quantum yields clearly overestimate the EET efficiency, as many other nonradiative modes of de-excitation are widely ignored.

Even under ambient conditions, the polymer discs show very different colors (dyes of equal absorbance). Under irradiation from a hand-held UV lamp, the dye mixture emits green light, whereas the dendritic solar concentrator shows bright reddish emission (Figure 6). Spectral data obtained on

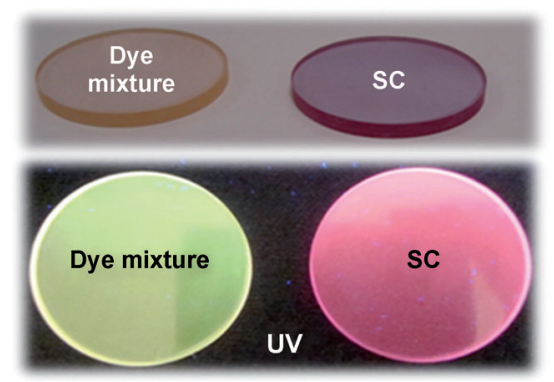

Figure 6. Monochromatization: SC embedded in epoxy resin slabs (right) and individiual dyes (BOD, mono-BOD-2, and di-BOD-2) mixed together at concentrations to have equal absorbances to that of SC at the absorption maxima (left). Bottom: front view under $360 \mathrm{~nm}$ illumination using a hand-held UV lamp.

excitation of the discs with a green laser also show signatures of energy transfer only in the unimolecular light harvester.

The results described herein clearly demonstrate that judicious selection of chromophores arranged in a cascade is likely to produce highly efficient luminescent solar concentrators. This is the first demonstration of the utility of a dendritic energy cascade in a slab waveguide and within a solid matrix. Conversion of solar radiation into a directed monochromatic light allows the use of just one type of more efficient and optimal solar cells in a much smaller area, thus reducing the overall cost significantly. Further optimization of photochemical and thermal stability, energy transfer efficiencies, and competing nonradiative processes is in progress and will be reported in due course.
Received: July 12, 2011

Published online: September 22, 2011

Keywords: bodipy · dendrimers · energy transfer .

light harvesting $\cdot$ solar cells

[1] F. H. Cocks in Energy Demand and Climate Change, Wiley$\mathrm{VCH}$, Weinheim, 2009.

[2] a) P. Menna, G. Di Francia, V. Laferrara, Sol. Energy Mater. Sol. Cells 1995, 37, 13-24; b) S. R. Wenham, M. A. Green, Prog. Photovoltaics 1996, 4, 3-33; c) B. Z. Tian, X. L. Zheng, T. J. Kempa, Y. Fang, N. F. Yu, G. H. Yu, J. L. Huang, C. M. Lieber, Nature 2007, 449, 885-U8.

[3] a) B. Rech, H. Wagner, Appl. Phys. A 1999, 69, 155-167; b) A. Goetzberger, C. Hebling, H. W. Schock, Mater. Sci. Eng. R 2003, $40,1-46$.

[4] a) I. Robel, V. Subramanian, M. Kuno, P. V. Kamat, J. Am. Chem. Soc. 2006, 128, 2385-2393; b) Y. Yin, A. P. Alivisatos, Nature 2005, 437, 664-670.

[5] a) B. O'Regan, M. Gratzel, Nature 1991, 353, 737-740; b) M. Grätzel, J. Photochem. Photobiol. C 2003, 4, 145-153; c) A. Hagfeldt, M. Grätzel, Acc. Chem. Res. 2000, 33, 269-277; d) M. K. Nazeeruddin, F. De Angelis, S. Fantacci, A. Selloni, G. Viscardi, P. Liska, S. Ito, T. Bessho, M. Grätzel, J. Am. Chem. Soc. 2005, 127, 16835-16847; e) S. Erten-Ela, M. D. Yilmaz, B. Icli, Y. Dede, S. Icli, E. U. Akkaya, Org. Lett. 2008, 10, $3299-$ 3302 ; f) S. Kolemen, Y. Cakmak, S. Erten-Ela, Y. Altay, J. Brendel, M. Thelakkat, E. U. Akkaya, Org. Lett. 2010, 12, $3812-$ 3815; g) S. Kolemen, O. A. Bozdemir, Y. Cakmak, G. Barın, S. Erten-Ela, M. Marszalek, J. H. Yum, S. M. Zakeeruddin, M. K. Nazeeruddin, M. Grätzel, E. U. Akkaya, Chem. Sci. 2011, 2, 949-954; h) S. Kim, J. K. Lee, S. O. Kang, J. Ko, J. H. Yum, S. Fantacci, F. De Angelis, D. Di Censo, M. K. Nazeeruddin, M. Gratzel, J. Am. Chem. Soc. 2006, 128, 16701-16707; i) J. J. Cid, J. H. Yum, S. R. Jang, M. K. Nazeeruddin, E. M. Ferrero, E. Palomares, J. Ko, M. Grätzel, Angew. Chem. 2007, 119, 8510 8514; Angew. Chem. Int. Ed. 2007, 46, 8358-8362; j) S. M. Feldt, E. A. Gibson, E. Gabrielsson, L. Sun, G. Boschloo, A. Hagfeldt, J. Am. Chem. Soc. 2010, 132, 16714-16724.

[6] D. Chemisana, Renewable Sustainable Energy Rev. 2011, 15, 603-611.

[7] W. G. J. H. M. van Sark, K. W. J. Barnham, L. H. Slooff, A. J. Chatten, A. Büchtemann, A. Meyer, S. J. McCormack, R. Koole, D. J. Farrell, R. Bose, E. E. Bende, A. R. Burgers, T. Budel, J. Quilitz, M. Kenedy, T. Meyer, D. M. Donega, A. Meijerink, D. Vanmaekelbergh, Opt. Express 2008, 16, 21773-21792.

[8] a) J. S. Batchelder, A. H. Zewail, T. Cole, Appl. Opt. 1979, 18, 3090-3110; b) J. S. Batchelder, A. H. Zewail, T. Cole, Appl. Opt. 1981, 20, 3733-3754; c) B. C. Rowan, L. R. Wilson, B. S. Richards, IEEE J. Sel. Top. Quantum Electron. 2008, 14, 13121322; d) R. Koeppe, N. S. Sariciftci, A. Buchtemann, Appl. Phys. Lett. 2007, 90, 181126; e) L. H. Slooff, E. E. Bende, A. R. Burgers, T. Budel, M. Pravettoni, R. P. Kenny, E. D. Dunlop, A. Buchtemann, Phys. Status Solidi RRL 2008, 2, 257-259; f) C. L. Mulder, L. Theogarajan, M. Currie, J. K. Mapel, M. A. Baldo, M. Vaughn, P. Willard, B. D. Bruce, M. W. Moss, C. E. McLain, J. P. Morseman, $A d v$. Mater. 2009, 21, 1-5; g) A. A. Earp, G. B. Smith, J. Franklin, P. Swift, Sol. Energy Mater. Sol. Cells 2004, 84, 411-426; h) C. L. Mulder, P. D. Reusswig, A. M. Velazquez, H. Kim, C. Rotschild, M. A. Baldo, Opt. Express 2010, 18, A79-90; i) R. Koeppe, O. Bossart, G. Calzaferi, N. S. Sariciftci, Sol. Energy Mater. Sol. Cells 2007, 91, 986-995.

[9] a) B. A. Schwartz, T. Cole, A. H. Zewail, Appl. Opt. 1977, 1, $73-$ 75; b) S. T. Bailey, G. E. Lokey, M. S. Hanes, J. D. M. Shearer, J. B. McLafferty, G. T. Beaumont, T. T. Baseler, J. M. Layhue, 
D. R. Broussard, Y.-Z. Zhang, B. P. Wittmershaus, Sol. Energy Mater. Sol. Cells 2007, 91, 67-75.

[10] M. J. Currie, J. K. Mapel, T. D. Heidel, S. Goffri, M. A. Baldo, Science 2008, 321, 226-228.

[11] a) M. D. Yilmaz, O. A. Bozdemir, E. U. Akkaya, Org. Lett. 2006, 8, 2871-2873; b) R. Guliyev, A. Coskun, E. U. Akkaya, J. Am Chem. Soc. 2009, 131, 9007-9013; c) O. A. Bozdemir, M. D. Yilmaz, O. Buyukcakir, A. Siemiarczuk, M. Tutas, E. U. Akkaya, Chem. Eur. J. 2010, 16,151-155; d) O. A. Bozdemir, Y. Cakmak, F. Sozmen, T. Ozdemir, A. Siemiarczuk, E. U. Akkaya, Chem. Eur. J. 2010, 16, 6346-6351; e) R. Ziessel, A. Harriman, Chem. Commun. 2011, 47, 611-631; f) A. Adronov, J. M. J. Fréchet, Chem. Commun. 2000, $1701-1710 ;$ g) J. M. Serin, D. W. Brousmiche, J. M. J. Fréchet, Chem. Commun. 2002, 2605-2607; h) T. Bura, P. Retailleau, R. Ziessel, Angew. Chem. 2010, 122, 6809 6813; Angew. Chem. Int. Ed. 2010, 49, 6659-6663; i) V. Balzani, P. Ceroni, M. Maestri, V. Vicinelli, Curr. Opin. Chem. Biol. 2003 7, 657-665; j) C.-W. Wan, A. Burghart, J. Chen, F. Bergstrom, L. B. A. Johansson, M. F. Wolford, T. G. Kim, M. R. Topp, R. M Hochstrasser, K. Burgess, Chem. Eur. J. 2003, 9, 4430-4441; k) Y. Ueno, J. Jose, A. Loudet, C. Perez-Bolivar, P. Anzenbacher, K. Burgess, J. Am. Chem. Soc. 2011, 133, 51-55; 1) J. Han, J. Jose, E. Mei, K. Burgess, Angew. Chem. 2007, 119, 17141717; Angew. Chem. Int. Ed. 2007, 46, 1684-1687; m) D. Holten, D. F. Bocian, J. S. Lindsey, Acc. Chem. Res. 2002, 35, 57-69; n) H. E. Song, M. Tanigushi, J. E. Diers, C. Kirmaier, D. F. Bocian, J. S. Lindsey, D. Holten, J. Phys. Chem. B 2009, 113 $16483-16493$

[12] a) S. Erbas, A. Gorgulu, M. Kocakusakogullari, E. U. Akkaya, Chem. Commun. 2009, 4956-4958; b) O. A. Bozdemir, R. Guliyev, O. Buyukcakir, S. Selcuk, S. Kolemen, G. Gulseren, T. Nalbantoglu, H. Boyaci, E. U. Akkaya, J. Am. Chem. Soc. 2010
132, 8029-8036; c) T. Ozdemir, S. Atilgan, I. Kutuk, L. T. Yildirim, A. Tulek, M. Bayindir, E. U. Akkaya, Org. Lett. 2009, 11, 2105-2107; d) R. Guliyev, O. Buyukcakir, F. Sozmen, O. A. Bozdemir, Tetrahedron Lett. 2009, 50, 5139-5141; e) L. L. Li, J. Y. Han, B. Nguyen, K. Burgess, J. Org. Chem. 2008, 73, $1963-$ 1970; f) J. L. Fan, K. X. Guo, X. J. Peng, J. J. Du, J. Y. Wang, S. G. Sun, H. L. Li, Sens. Actuators B 2009, 142, 191; g) X. Qi, E. J. Jun, L. Xu, S.-J. Kim, J. S. J. Hong, Y. J. Yoon, J. Yoon, J. Org. Chem. 2006, 71, 2881-2884; h) X. Qi, S. K. Kim, S. J. Han, L. Xu, A. Y. Jee, H. N. Kim, C. Lee, Y. Kim, M. Lee, S.-J. Kim, J. Yoon, Tetrahedron Lett. 2008, 49, 261-264; i) S. Ozlem, E. U. Akkaya, J. Am. Chem. Soc. 2009, 131, 48-49; j) A. Loudet, K. Burgess, Chem. Rev. 2007, 107, 4891-4932; k) Y. W. Wang, A. B. Descalzo, Z. Shen, X. Z. You, K. Rurack, Chem. Eur. J. 2010, 16, 2887-2903; 1) A. B. Descalzo, H. J. Xu, Z. L. Xue, K. Hoffmann, Z. Shen, M. G. Weller, X. Z. You, K. Rurack, Org. Lett. 2008, 10, 1581-1584; m) Y. Zhou, J. W. Kim, R. Nandhakumar, M. J. Kim, E. Cho, Y. S. Kim, Y. H. Jang, C. Lee, S. Han, K. M. Kim, J.-J. Kim, J. Yoon, Chem. Commun. 2010, 46, 6512$6514 ;$ n) Y. Zhou, J. W. Kim, M. J. Kim, W.-J. Son, S. J. Han, H. N. Kim, S. Han, Y. Kim, C. Lee, S. Kim, D. H. Kim, J.-J. Kim, J. Yoon, Org. Lett. 2010, 12, 1272-1275.

[13] a) K. Umezawa, Y. Nakamura, H. Makino, D. Citterio, K. Suzuki, J. Am. Chem. Soc. 2008, 130, 1550-1551; b) K. Rurack, M. Kollmannsberger, J. Daub, Angew. Chem. 2001, 113, 396399; Angew. Chem. Int. Ed. 2001, 40, 385-387; c) A. Haefele, C. Zedde, P. Retailleau, G. Ulrich, R. Ziessel, Org. Lett. 2010, 12, 1672-1675; d) D. C. Wang, J. L. Fan, X. Q. Gao, B. S. Wang, S. G. Sung, X. J. Peng, J. Org. Chem. 2009, 74, 7675; e) O. Buyukcakir, O. A. Bozdemir, S. Kolemen, S. Erbas, E. U. Akkaya, Org. Lett. 2009, 11, 4644-4647. 